\title{
FOREIGN OWNERSHIP AND FINANCIAL DISCLOSURE IN CENTRAL AND EASTERN EUROPE
}

\author{
Alina TARAN1 ${ }^{\text {, R. M. Ammar ZAHID22, Marilena MIRONIUC }}{ }^{3}$
}

DOI: 10.1515/tjeb-2017-0010

It is recognized that multinational corporations (MNC) have played a significant role in the recent worldwide accounting reform. This study analyses the influence of foreign ownership, and MNC on financial disclosure practices of listed companies from Central and Eastern European countries (CEE). The possible reverse effect is also considered, and thus, the role of disclosure in attracting foreign investments is investigated. Fixed effects panel analysis has been conducted for 2005-2015 period, in the context of partial IFRS adoption in CEE. Contrary to hypothesized expectations, the influence of foreign ownership on the extent of disclosure is negative. As foreign investors in CEE are dominantly corporations, it seems they impose their own reporting policies or report detailed group information, which may diminish the disclosure of foreign subsidiaries. Moreover, it was found that foreign investors are not sensitive to changes of items in reported information. This evidence raises questions regarding the purpose, and the impact of disclosure on financial markets. Overall, this study gives a signal to standard-setters about reporting practices at regional level, and adds an original empirical contribution to reporting behavior and corporate transparency literature. Moreover, it invites to further research on reporting practices of companies with foreign ownership.

Keywords:

Foreign ownership, Multinational corporation ownership, Financial disclosure, Central and Eastern European countries

JEL Classification: M410, M160, M480

\footnotetext{
${ }^{1}$ PhD Student, Doctoral School of Economics and Business Administration, "Alexandru loan Cuza" University of Iasi, Romania

${ }^{2}$ PhD Student, Izmir University of Economics, Izmir, Turkey

3 ProfessorPhD, Faculty of Economics and Business Administration, "Alexandru Ioan Cuza" University of Iasi, Romania
} 
Taran, A., Zahid, R.M.A., Mironiuc, M. (2017).

\section{Introduction}

In the actual context of global mobility of investors and capitals, the listed companies have local and foreign shareholders, such as institutional investors, state authorities, corporations, individuals or employees. Their distinct nature and interests affect the activity and performance of the owned entities (Bokpin \& Isshaq, 2009; Xia \& Walker, 2014; Akman et al., 2015; Chen et al., 2017), and under certain circumstances, their influence may be seen also in financial reporting practices. For example, it was shown that if domiciled in countries oriented to high investor protection, foreign investors contribute to improvement of financial reporting quality of entities they invested in (Beuselinck et al., 2017). However, the aspects related to foreign investors influence on financial reporting and the role of disclosure in attracting foreign investors were studied on a small extent (Hansen et al., 2015; Scaltrito, 2016; Beuselinck et al., 2017), and the problem of disclosure remains a debatable issue in corporate reporting literature (Beyer et al., 2010).

This study aims to explore the relationship between foreign ownership, respective corporate foreign ownership, and financial disclosure practices of listed companies from Central and Eastern European countries (CEE region): Bosnia and Herzegovina, Bulgaria, Croatia, Czech Republic, Estonia, Hungary, Latvia, Lithuania, Macedonia, Poland, Romania, Serbia, Slovakia, Slovenia, Turkey, and Ukraine. While the focus of previous studies was on developed or single countries (Scaltrito, 2016), to the best of our knowledge, this is one of the first studies which investigates the foreign ownership influence, and financial disclosure practices in the region. Moreover, it applies to the recent economic and institutional context, and differentiates between broad category of foreign investors and corporate investors. Besides mixed accounting regulatory frameworks, being later members of European Union (EU) or nonmembers, respective adopters, partially-adopters or non-adopters of IFRS, CEE countries distinguish by historical and cultural background, banking-financing orientation and prevalence of statutory-control. CEE countries are generally competing for foreign investments that may enhance their economic growth, and thus, it may be assumed that they may be sensitive to the role of disclosure in attracting foreign investors (Hansen et al., 2015). In the same time, foreign ownership may influence also reporting practices of CEE companies, on the benefit of overall stakeholders. For consistency of analysis, these associations are explored on a ten-year period, 2005-2015, coinciding with the mandatory IFRS adoption for consolidation purposes of public entities in EU.

Our findings reveal that foreign ownership, respective MNC ownership influence the regional financial reporting practices in $\mathrm{CEE}$, having a negative impact on the extent of disclosure. One explanation may be the inclusion of investees in the consolidation perimeter of MNC. This imply that information may be only disclosed at the group-level. In addition, competitive or strategic interests may determine reporting entities to be cautious in their reporting. 
Taran, A., Zahid, R.M.A., Mironiuc, M. (2017).

Moreover, the analyzed relation is not mutual, as foreign investors and foreign corporate investors do not react to the changes in extent of financial disclosure. Accounting professionals, managers, standard-setters, and policy-makers may consider these findings for their practices and decision-makings. In addition, researchers are invited to further explore the relation between foreign ownership and accounting practices, and especially the influence of MNC on financial reporting tendencies from operating countries.

The rest of the paper is structured as following: in the next section, literature insights and hypotheses development are presented; then, methodology and data selection are discussed, followed by the sections of results and conclusions.

\section{Literature Review and Hypotheses Development}

It is thought that foreign companies differ from local entities due to dimension and scale effect benefits, experience and notoriety in international transactions, superior technologies, or distinctive organizational and managerial structures (Narula \& Pineli, 2016). However, the idea of superiority of foreign firms is not commonly accepted (Nakano \& Nguyen, 2013), and differences may be explained by economic context, governmental control over investors (Chen et al., 2017), and other institutional factors. In terms of financial reporting practices, multinational corporations represent key actors that express the need of comparability and transparency in international accounting (Zimmermann \& Werner, 2013). Thus, it may be assumed that their practices influence the financial reporting from countries where they operate. Khanna et al. (2004) found that foreign interactions of companies facilitates the change of best practices and leads to similarities in disclosure and corporate governance.

Scaltrito (2016) compiled an extended review of disclosure literature and summarized the theories that explain the role of supplemental financial information. From the perspective of stakeholder theory, financial reporting reflects a responsibility of companies towards stakeholders, for their involvement, interests and interactions with reporting entities. According to legitimacy theory, financial disclosure helps companies to share their results of operations and to be perceived by society, since their existence is based on serving the population needs of goods and service. Agency theory relates to asymmetry between internal and external users of information with regard to involvement in and awareness of activity and performance of the firms. Thus, financial reporting provides information to external users in order to overcome the effects of asymmetry. In addition, details about the firm activity may be disclosed to signal its performance, to enhance capital raising, to prove entity's position in the economy, or to avoid additional costs related to lack of transparency, as explained by signaling theory, capital need theory, political cost theory, and cost-benefit theory (Scaltrito, 2016). 
Taran, A., Zahid, R.M.A., Mironiuc, M. (2017).

In an analysis of factors that may explain variation of voluntary disclosure among Swedish companies, Broberg et al. (2010) noticed the positive influence of foreign ownership, among other factors related to ownership structure, pressure of capital markets, regulation, size, industry and company leverage. A longitudinal study of voluntary disclosure in Kenya proved also that company related factors, corporate governance factors, and foreign and institutional ownership influence financial reporting practices (Barako et al., 2006). Wang et al. (2008) noticed a positive effect of foreign ownership on disclosure of Chinese companies. They explained that foreign investors are facing more difficulties in understanding foreign reports due to language barriers, and have limited knowledge about the companies. That is why additional disclosure may be especially significant for them. Other studies found negative or not significant evidence of the influence of foreign ownership on financial disclosure (Jankensgard, 2018). Overall, although the previous studies took into consideration diverse categorization of shareholders, their results indicate there is a relationship between ownership and disclosure, on different regions or points in time. This led to assumption that foreign ownership is associated with disclosure practices of listed companies from CEE, foreign investment being an influent determinant of market development in the region. Therefore, our first hypothesis is:

H1: Foreign ownership positively influences future financial disclosure practices of listed companies from CEE region.

Although local or foreign, the nature of shareholders can be diverse. According to Chau and Gray (2010) family shareholding has a positive effect on voluntary disclosure of companies from Hong-Kong. Fang et al. (2015) showed that US institutional ownership contributes to increased comparability in financial reports of their investees. Thus, studies emphasized that the different categories of investors may distinctively influence reporting entities. About institutional investors, it is proved that they efficiently monitor the management of their investee (Imam \& Malik, 2007; Hsu \& Wang, 2014; Nashier \& Gupta, 2016), but their interest is mainly financial, without active and long-term perspectives of involvement in the activities of the firms (Douma et al., 2006). This may lead to a limited influence on extent of disclosure of their investees (Fang at el., 2015). However, corporate shareholders are strategically tied to their subsidiaries, and their influence needs to be distinctively analyzed. On the one hand, they may enhance disclosure and comparability of financial information, as aligned to the parent corporate reporting practices. On the other hand, parent or investing corporations may internally have access to information about their subsidiaries. That is way they may not put pressure on disclosures of their foreign affiliates. Thus, both positive and negative influences may occur, and we investigate their influence in CEE context, based on the following hypothesis:

H2: Foreign corporate ownership influences future financial disclosure practices of listed companies from CEE region. 
Taran, A., Zahid, R.M.A., Mironiuc, M. (2017).

Literature insights indicate that each type of shareholders may directly affect the management and strategic decisions of the investee companies (Choi et al., 2012) by having different informational requirements and interests (Douma et al., 2006; Chen et al., 2017). Their influence can vary over time or regions due to organizational structure of the companies or due to economic, legal, social or cultural context (Douma et al., 2006; Xia \& Walker, 2014). Besides that, the role and quality of financial reporting in attracting foreign investors was also studied in different contexts and regions (Mangena \& Tauringana, 2007; Bokpin \& Isshaq, 2009; DeFond et al., 2011; Hansen et al., 2015). Overall, it was noticed that increased comparability, financial transparency, and additional information positively influence foreign ownership in countries with high level of investors' protection and strong corporate governance practices. However, corporate disclosure is a broad and abstract concept with various dimensions. For the purpose of our study, we refer to financial disclosure, by which it is understood information provided in the financial statements, including notes. The aforementioned studies highlight the benefits of disclosure, but it is necessary to be reminded that any provided information has its own costs, and constraints. Furthermore, not only the extent of disclosure matters, but also its quality and timeliness, otherwise, it can be wondered why companies do not provide full disclosure, or why an optimal level of disclosure cannot be determined. A comprehensive discussion of concerns regarding disclosure and corporate reporting is presented in Beyer et al. (2010), where the state of play in terms of disclosure literature and research are critically analyzed. Besides all these explanations, disclosure is considered to enhance competitiveness and credibility of reporting entities (Scaltrito, 2016), reducing uncertainty and supporting decisions (Alhazaimeh et al., 2014). These benefits led to an enhanced performance of firm (Wang et al., 2008), and are reflected in an increased market capitalization (Alhazaimeh et al., 2014). Thus, disclosure have a key role in investment decisions, and may represent a factor in attracting foreign investors (Mangena \& Tauringana, 2007; Bokpin \& Isshaq, 2009; DeFond et al., 2011; Hansen et al., 2015). We expect that this association may apply to CEE context, and therefore, we assume that extended financial disclosure attracts foreign investors and foreign corporations in CEE markets, as stated by the following hypothesis:

\section{H3: A higher level of financial disclosure in CEE attracts foreign investors.}

However, the differences among the diverse types of shareholders may be important in investment decisions (Thomsen \& Pedersen, 2000). Institutional investors react in a prompt manner to any signals about their investees. However, strategic investors such as corporations are typically characterized by long-term affiliations, and their investment decisions involve more strategic judgement. Thus, it can be expected that increased disclosure contributes to investments decisions of strategic foreign corporate investors, as stated by the following hypothesis:

H4: A higher level of financial disclosure in CEE attracts foreign corporate investors. 
Taran, A., Zahid, R.M.A., Mironiuc, M. (2017).

In their race to attract foreign investors, companies may tend to disclosure more detailed information that emphasizes their growth potential. On the other hand, this influence may not be visible immediately, strategic investors being firstly concerned about the overall risk and benefits associated with their prospective investments (Hansen et al., 2015). Our investigation aims to shed light on these aspects, evaluating the power of disclosure mechanism in CEE emerging and frontier markets.

\section{Methodology and Data}

We propose to investigate the association between foreign ownership, respective foreign corporate ownership, and financial disclosure in CEE countries. We expect that foreign investors and MNC may influence disclosure practices of CEE companies, and vice versa. In consequence, we empirically test our research hypotheses, taking into account the time of publicly reporting and the implementation time of reporting changes. As further explained, the variables were selected in line with prior literature.

Firstly, as in most of the previous studies (Khanna et al., 2004; Wang et al., 2008; Bokpin \& Isshaq, 2009; Chau \& Gray, 2010; Scaltrito, 2016), the extent of disclosure and information transparency was measured by an original unweighted index. We developed a financial disclosure index in order to capture financial disclosure of some relevant aspects, without taking into account the overall financial disclosure that a company may provide. Disclosure index (DI) was determined based on the supplemental reporting of the following items and reporting methods applied: Audit Fees; other fees paid to auditors (such as Audit-Related Fees; Tax Fees; All Other Fees Paid to Auditor) and Cash-flow determined based on direct method. The index reflects the percentage of disclosed items out of the selected three aspects. Random tests of financial statements of companies from different countries indicated that some of the selected aspects may be partially, completely or not at all reported, and we assume that legal enforcement and changes in national regulation may influence reporting practices of the companies. The items were selected based on the list of supplemental information reported, available on Thomson Reuters Eikon database, and reflects information presented in the notes of financial statements, or in the cash-flow statement (which may be reported based on direct or indirect method of cash-flow calculation). Thus, the index is composed of items for which the reporting entities have a high level of flexibility. Disclosure of audit fee and other fees paid to auditors is considered to be a sign of enhanced audit and reporting quality, diminishing the suspicions of conflict of interests and economic dependence between auditors and reporting entities (Chen, 2016), whereas cash-flow disclosures contribute to firm valuation (Hoque \& Rakow, 2016). Direct method of reporting cash-flow is considered more comprehensive, and having more predictive ability than indirect method (Bradbury, 2011). 
Taran, A., Zahid, R.M.A., Mironiuc, M. (2017).

Secondly, foreign ownership is represented under two forms: as foreign ownership regardless of the types of shareholders, and foreign corporate ownership, which proxies the affiliation between foreign companies and local subsidiaries. Foreign Ownership (FO) represents the ratio of shares held by foreign investors on the total common outstanding shares of the company. Foreign investors can be strategic entities, such as corporations, government agencies, holding companies, individual investors, or non-strategic investors, represented by investment management funds or brokerage firms. Foreign corporate ownership (FOC) is determined as the ratio of shares held by foreign corporate investors on the total common outstanding shares of the company. Since previous studies found that foreign institutional investors have a stronger influence of reporting quality (Beuselinck et al., 2017), or analyzed the case of family shareholding (Chau \& Gray, 2010), this research considers the special role of corporate strategic investors, which expresses the MNC ownership effect. Overall, shareholders are classified as foreign if they are registered in a country other than the country of incorporation of the investee firm.

Thirdly, other reporting and corporate related factors were defined as control variables. These variables were found to be significantly related to foreign ownership (Hansen et al., 2015), or financial disclosure in prior studies. Binary variable Financial Reporting Standards (FRS) indicates which standards were applied by CEE companies, and surprises the effect of change of country regulation over time. Its values are coded as following: 0 for National reporting standards; and 1 for International Financial Reporting Standards (IFRS). Previous literature indicates that IFRS enhance transparency, and may contribute to attract foreign investments (Broberg et al., 2010; DeFond, 2011; Hansen et al., 2015). Binary variable Group shows if disclosed items refer to consolidated or individual financial statements, being coded as 0 for Individual financial statements, and 1 for Consolidated financial statements. Moreover, group variables take into account the organizational structure effect. Size (LnTA), determined as natural logarithm of total assets, captures the sensitiveness of reporting entities to information costs, and dimensions of reporting entities. It is expected that larger firms may have a higher level of disclosure (Alhazaimeh et al., 2014; Leung \& Verriest, 2015; Scaltrito, 2016; Beuselinck et al., 2017). Furthermore, this variable controls for the operating capacity, and business model differences among companies. Subsequently, this may enhance foreign investors' interest in local firms. Return on Assets (ROA) surprises the performance effect, being expected that more profitable firms may easily afford disclosure costs, and may disclose more information (Fang et al., 2015; Hansen et al., 2015; Guay et al., 2016; Scaltrito, 2016), if that it is on their benefit. In addition to book measurement of performance, Market-to-Book ratio (MTB) expresses the perception of the company on the financial market, and controls for investors' interest in the reporting entity. Ratio of foreign direct investment in gross domestic product (FDI_GDP) reflects the country effect and attractiveness to foreign investments (Hansen et al., 2015), and covers the institutional and environmental aspects that may influence foreign investment decisions. 
Taran, A., Zahid, R.M.A., Mironiuc, M. (2017).

To analyze the influence of foreign ownership and foreign corporate ownership on the extent of financial disclosure of CEE companies over time, panel regression method is applied. Thus, it was accounted for the heterogeneity among firms, and for period-specific events. Two panel least squares regression models are estimated, as follows:

$$
\begin{aligned}
& \boldsymbol{D I}_{\boldsymbol{i}, \boldsymbol{t}}=\alpha_{\boldsymbol{i}}+\beta_{\mathbf{1}} F_{i, t-1}+\Sigma_{j} \beta_{j} C_{i, j, t}+\varepsilon_{i, t} \\
& \boldsymbol{D I}_{\boldsymbol{i}, \boldsymbol{t}}=\alpha_{\boldsymbol{i}}+\beta_{\mathbf{1}} F C O_{i, t-1}+\Sigma_{j} \beta_{j} C_{i, j, t}+\varepsilon_{i, t}
\end{aligned}
$$

Where $D I_{i, t}$ represents Disclosure Index as dependent variable which expresses the percentage of disclosed items out of the selected items for the firm $i$ as of year $t$; FO represents Foreign Ownership is the ratio of shares held by foreign investors on the total common outstanding shares of the firm $i$ for the year $t, \mathrm{FCO}=$ Foreign Corporate Ownership is the ratio of shares held by foreign corporate investors on the total common outstanding shares of the company, and $\mathrm{C}=$ Control are the selected control variables which may affect the relationship between disclosure and foreign, respective MNC ownership, as mentioned above. It is assumed that the effect of ownership on financial reporting practices may be visible in time, and not on the same financial year. This is explained by the time needed for a first evaluation of the company reporting practices, and a first participation of new investors in annual shareholders' meetings, followed by the expressed request of disclosure changes. Therefore, one-year lag of foreign ownership and foreign corporate ownership is considered in estimating the panel regressions, as explained by equations (1) and (2).

As mentioned in literature review and hypotheses development section, the reverse relations may also apply, and thus, the extended disclosure may attract more foreign investors. Eventual changes in ownership structure are expected to occur after publication of yearly financial statements. In order to test the effect of financial reporting on foreign ownership and foreign corporate ownership, equations (3) and (4) are estimated taking into account one year lagged disclosure index. In these panel regression models, variables are the same as defined above.

$$
\begin{gathered}
\boldsymbol{F O}_{i, \boldsymbol{t}}=\alpha_{\boldsymbol{i}}+\beta_{\mathbf{1}} D I_{i, t-1}+\Sigma_{j} \beta_{j} C_{i, j, t}+\varepsilon_{i, t} \\
\boldsymbol{F C O}_{i, t}=\alpha_{\boldsymbol{i}}+\beta_{\mathbf{1}} D I_{i, t-1}+\Sigma_{j} \beta_{j} C_{i, j, t}+\varepsilon_{i, t}
\end{gathered}
$$

Selected sample consists of listed companies from CEE countries (Bosnia and Herzegovina, Bulgaria, Croatia, Czech Republic, Estonia, Hungary, Latvia, Lithuania, Macedonia, Poland, Romania, Serbia, Slovakia, Slovenia, Turkey, and Ukraine). Countries were selected in line with Deloitte top 500 firms from Central Europe in 2016, which highlights the dominance of foreign ownership/ MNC ownership in the region. In addition, Turkey was included as a representative emerging market highly related to European economies through trade and institutional characteristics. For each of the 16 countries in the region, maximum 500 
Taran, A., Zahid, R.M.A., Mironiuc, M. (2017).

companies per country, ranked by market capitalization, are included in the sample, in order to maintain a relative balance among number of companies from each country. Companies with non-available data are excluded, and thus, from an initial sample of 3938 entities, only 1100 entities are considered for analysis. Corporate-related data was retrieved from Thomson Reuters Eikon Database, and country-level data was obtained from World Development Indicators of World Bank. The analyzed period is 2005-2015, covering the period since IFRS became mandatory in European Union for consolidated financial reporting of listed companies. This period corresponds to the remarkable spread of IFRS recognition all over the Europe, and all over the world, and to admission of many CEE countries in EU. These events certainly impacted financial markets development, foreign investments, and overall economic development of the region. The final sample, diminished due to missing data, contains 8727 firm-years observations. The evolution of foreign ownership, and foreign corporate ownership over the analyzed period is presented in Table 1.

Table 1. Foreign ownership mean values.

\begin{tabular}{cccccccccccc}
\hline & 2005 & 2006 & $\mathbf{2 0 0 7}$ & $\mathbf{2 0 0 8}$ & $\mathbf{2 0 0 9}$ & $\mathbf{2 0 1 0}$ & $\mathbf{2 0 1 1}$ & $\mathbf{2 0 1 2}$ & $\mathbf{2 0 1 3}$ & $\mathbf{2 0 1 4}$ & $\mathbf{2 0 1 5}$ \\
\hline $\mathbf{N}$ & 375 & 487 & 615 & 723 & 800 & 868 & 890 & 936 & 996 & 1010 & 1027 \\
\hline \multicolumn{8}{c}{ F0 and F0C (for CEE countries) } \\
\hline F0 (mean) & 0.147 & 0.119 & 0.126 & 0.126 & 0.125 & 0.125 & 0.124 & 0.129 & 0.133 & 0.139 & 0.254 \\
\hline FOC (mean) & 0.095 & 0.077 & 0.076 & 0.080 & 0.089 & 0.090 & 0.088 & 0.093 & 0.094 & 0.099 & 0.148 \\
\hline
\end{tabular}

$N$ - number of firms; FO - Foreign Ownership; FOC - Foreign Corporate Ownership

Besides the increased number of available observations over the years, it can be noticed that in average, foreign investments, respective foreign corporate investments follow an increasing trend, after a visible drop in 2006 in comparison with 2005. This break-point can be explained by the politico-economic reforms in the region associated with the new membership, or expected membership of individual CEE countries in EU. Even though, on average, the foreign ownership in the region represents around $12 \%$ to $14 \%$ of overall firm ownership. Foreign corporations, as strategic investors held around $8 \%$ to $10 \%$ of total shares of CEE companies. Year 2015 may be remarked as being characterized by a considerable increase in foreign owners (25\%) and MNC (15\%) investing in CEE financial markets, thus reflecting a recover after the recent financial crisis. These statistics are illustrated also in Figure 1, in comparison with evolution of disclosure index, and its component items (disclosure of audit fees, other fees related to auditors, and preference for direct cash-flow method). 
Taran, A., Zahid, R.M.A., Mironiuc, M. (2017).
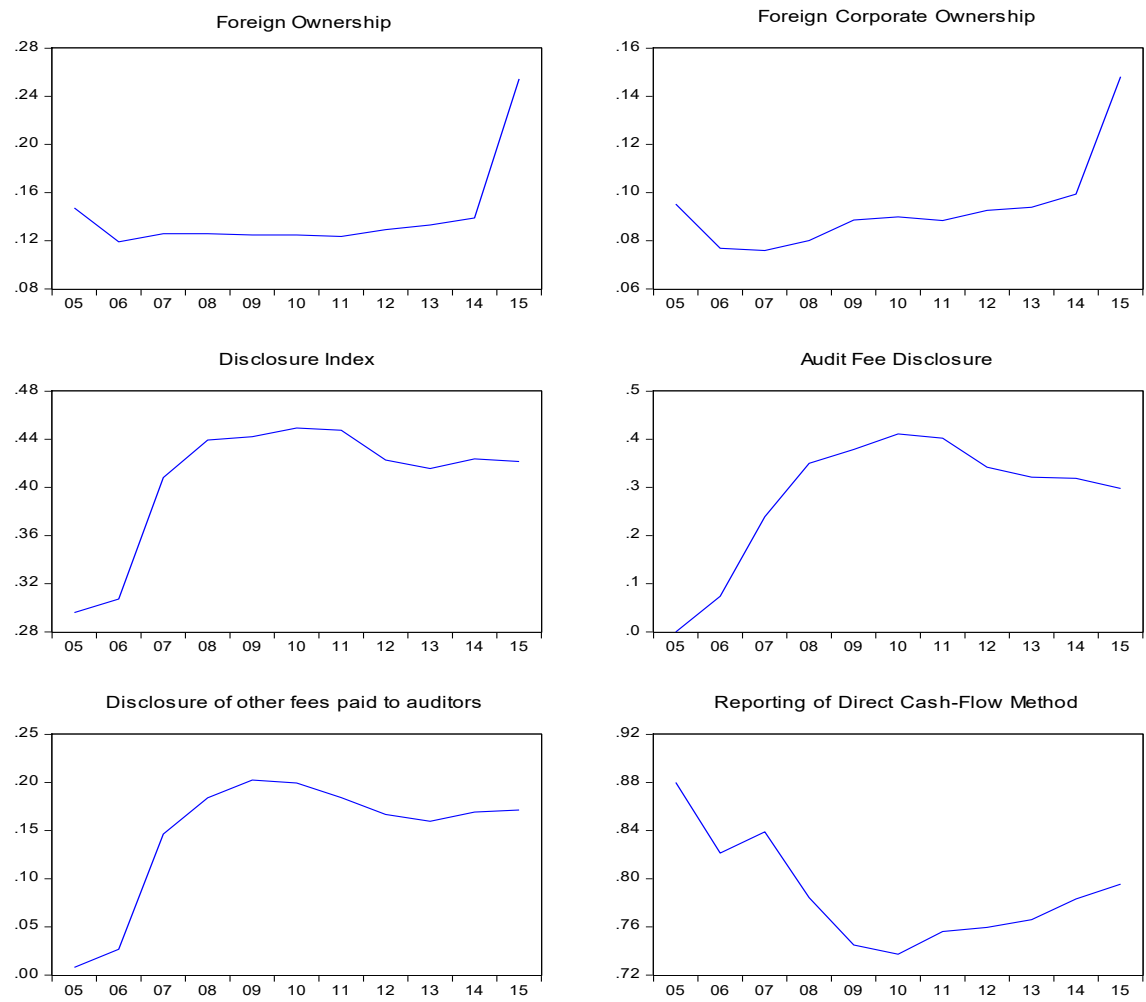

Figure 1. Evolution of foreign ownership, disclosure index and disclosed elements (mean values).

Source: Authors' compilation

On average, the extent of disclosure in CEE region mainly increased during 2005-2011 period, a slight decrease occurring after 2011. In most of the countries, the extent of disclosure had a similar variation. This may be explained by the IFRS adoption country by country, which led to a change of reporting policies at company-level. However, the extend of disclosure is low, companies being reluctant in presenting additional information related to their expenses in the notes of financial statements or in the cash-flow statement. A surprising decrease in extent of disclosure in the last 2-4 years (2013-2015, respective 2011-2015) signals a new changing trend in financial reporting practices, probably determined by changes in accounting regulations and enforcement at European or country level. Explanations such as a limited disclosure provided by newly listed companies, or a differentiation among categories of listed companies can be also considered. Thus, our descriptive analysis revealed recent fluctuations in disclosure and foreign ownership, which may need to be further investigated in order to be determined how they influence the financial reporting systems, and investments patterns in the region. In line with the purpose of our study, it is observed that increase in foreign ownership can be related to disclosure of audit related information, at least during 2005-2011 period. In contrast, cash-flow reporting based on direct method seems to become more popular in the recent years, 2011-2015, following an increasing trend, similar to foreign 
Taran, A., Zahid, R.M.A., Mironiuc, M. (2017).

ownership evolution. Based on these evidence, we expect that our hypotheses may be, at least partially, confirmed.

Descriptive statistics of the overall estimated and control variables are presented in Table 2. Mean level of disclosure index is $41.7 \%$, which suggests that companies report mainly onetwo items, as we expected to be disclosed by all reporting entities. However, the range of values vary between the extreme values, 0 and 1 , indicating that there are companies completely reluctant to disclosure and companies opened to highly transparent financial reporting practices. Percent of foreign investments in CEE companies is, on average, relatively small. Mean value of foreign ownership is $14.4 \%$ and of foreign corporate ownership is $9.6 \%$, with considerable variations. On average, it may be expected that foreign owners are not able to influence reporting practices due to their small ownership and controlling powers, but further empirical tests are needed to investigate this aspect. The size, performance and market value of selected companies varies, as well, within the sample, and over the period. $84.4 \%$ of the firms applied IFRS for their reporting, and a majority of $78.5 \%$ are group companies. Thus, the analyzed sample covers a diversity of firms, with various financial profiles. Moreover, CEE countries receive annually $3.6 \%$ foreign direct investments as percent of gross domestic product. However, there are major differences among countries during the analyzed period, ratio of FDI to GDP ranging from considerable divestments to massive foreign investments. This means that there are foreign investors who leave some of the countries, or invest in others.

Table 2. Descriptive Statistics.

\begin{tabular}{cccccccccc}
\hline & DI & FO & FOC & FDI_GDP & LnTA & FRS & GROUP & ROA & MTB \\
\hline Mean & 0.417 & 0.144 & 0.096 & 3.597 & 18.578 & 0.844 & 0.785 & 2.968 & 2.892 \\
\hline Median & 0.333 & 0.014 & 0.000 & 2.949 & 18.426 & 1.000 & 1.000 & 2.762 & 0.948 \\
\hline Max & 1.000 & 0.998 & 0.998 & 50.742 & 25.356 & 1.000 & 1.000 & 264.256 & 5523.028 \\
\hline Min & 0.000 & 0.000 & 0.000 & -16.077 & 6.398 & 0.000 & 0.000 & -218.519 & -285.560 \\
\hline Std. Dev. & 0.300 & 0.251 & 0.223 & 4.778 & 2.003 & 0.363 & 0.411 & 14.265 & 68.662 \\
\hline
\end{tabular}

DI represents Disclosure Index, FO Foreign Ownership, FOC Foreign Corporate Ownership, FDI_GDP Foreign direct investment percentage of GDP, LnTA Natural Logarithm of Total Assets, FRS Financial Reporting Standards dummy variable: 0 for national accounting standards and 1 for IFRS, GROUP dummy variable: 0 for Individual financial statements and 1 for Consolidated financial statements, ROA Returns on Total Assets, MTB Market-to-Book ratio.

\section{Results}

Empirical analysis has been conducted using the statistical software E-views, version 9.5. First, the intensity of relationships between selected variables has been determined through correlation analysis, as presented in Table 3. Consistent with our expectations there is significant, but small correlation between disclosure index and foreign ownership, respective foreign corporate ownership data. Most of the control variables are significantly correlated 
Taran, A., Zahid, R.M.A., Mironiuc, M. (2017).

Foreign Ownership and Financial Disclosure in Central and Eastern Europe

with disclosure index, foreign ownership, or among each other, but the intensity of all these correlations is small. Multicoliniarity assumption was tested, and values of variance inflation factor (VIF) for the estimated models are less than 2. This means that estimations of regression analysis are not biased by collinearity threat.

Table 3. Pearson Correlation Matrix.

\begin{tabular}{|c|c|c|c|c|c|c|c|c|c|}
\hline & DI & FO & FOC & FDI_GDP & LnTA & FRS & GROUP & ROA & MTB \\
\hline DI & 1.000 & & & & & & & & \\
\hline FO & $0.146 *$ & 1.000 & & & & & & & \\
\hline FOC & $0.125 *$ & $0.884 *$ & 1.000 & & & & & & \\
\hline FDI_GDP & $-0.103 *$ & 0.007 & -0.005 & 1.000 & & & & & \\
\hline LnTA & $0.077 *$ & $0.222 *$ & $0.120 *$ & $-0.066 *$ & 1.000 & & & & \\
\hline FRS & $0.172 *$ & $0.070 *$ & $0.033 *$ & -0.019 & $0.194 *$ & 1.000 & & & \\
\hline GROUP & $0.144 *$ & $0.077 *$ & $0.033 *$ & $-0.034 *$ & 0.277 * & $0.353 *$ & 1.000 & & \\
\hline ROA & $0.056 *$ & 0.006 & -0.005 & $0.035 *$ & $0.072 *$ & 0.002 & -0.009 & 1.000 & \\
\hline MTB & -0.005 & $0.030 *$ & $0.030 *$ & -0.001 & -0.013 & -0.014 & 0.011 & 0.005 & 1.000 \\
\hline
\end{tabular}

* Significant correlation at 0.01 level.

DI represents Disclosure Index, FO Foreign Ownership, FOC Foreign Corporate Ownership, FDI_GDP Foreign direct investment percentage of GDP, LnTA Natural Logarithm of Total Assets, FRS Financial Reporting Standards dummy variable: 0 for national accounting standards and 1 for IFRS, GROUP dummy variable: 0 for Individual financial statements and 1 for Consolidated financial statements, ROA Returns on Total Assets, MTB Market-to-Book ratio.

Since our analysis employs firm level data from 16 different countries, an OLS model may be biased because of unobserved heterogeneity. To account for this, firm fixed effects model specifications which control the firms unobserved heterogeneity were applied. Moreover, in order to test the validity of this model, additional tests were considered, such as redundant fixed effects test (Likelihood ratio test), and correlated random effects estimations (Hausman Test). Results of the both tests for all the estimated models showed that firm fixed effect is the most appropriate model specification for the present analysis. In order to analyze the association between disclosure and foreign ownership, four firm fixed effects panel regression models have been estimated according to the models described on the methodology section. The results are presented in Table 4.

Model I presents the impact of foreign ownership on financial disclosure. The results indicate that foreign ownership has a significant impact on future information disclosed in financial statements. Surprisingly, a higher level of foreign ownership determines a decrease in extent of future disclosure. This contradicts the hypothesis $\mathrm{H} 1$, and our expectation for a significant, but positive relationship. This finding can be partially explained by the fact that foreign investors question the credibility of financial reporting of all firms regardless of their level of 
Taran, A., Zahid, R.M.A., Mironiuc, M. (2017).

transparency in countries perceived as having a weak investor protection (Hansen et al., 2015). Thus, they may question additional disclosure, or prefer reporting practices comparable with those used in their country of origin (Fang et al., 2015). Most of the control variables have a significant influence on disclosure index, suggesting that disclosure is dependent on the size and performance of the entity, financial reporting standards that are applied, and national setting favorable or not to foreign investments. Thus, it seems that company-related factors may both enhance or diminish financial disclosure in the notes of financial statements or in the cash-flow statement. Interesting, adoption of IFRS seems to determine a decrease of disclosure, or just a preference for indirect cash-flow method of reporting. Moreover, well performing firms, tend to have a limited disclosure, maybe because they count on their positive financial results for signaling their activity. In the same time, country-related factors proxied by FDI to GDP ratio do not promote supplementary disclosure, or do not have a direct influence on firms' practices.

In the case of foreign corporate ownership, as estimated by Model II, the results are similar. This may be explained by a secrecy policy adopted inside the group companies, or by exemptions that may be applied to subsidiaries if detailed information is reported at the group level. These results support hypothesis $\mathrm{H} 2$ which states there is a significant influence of foreign corporate ownership on future disclosure practices of listed companies from CEE, with the expectation that the influence may be either positive or negative. The empirical investigation reveals that affiliation to a foreign entity rather diminishes disclosure practices of CEE entities, in terms of expenses disclosure, costs of audit and audit related services, and cash-flow transparency. These findings are partially in contradiction to Beuselinck et al. (2017) who found that increases in foreign ownership lead to increases in financial reporting quality in South-European countries (Greece, Italy, Portugal and Spain). However, their evidence applies only if the foreign shareholders are registered in countries with strong investor protection mechanisms. Thus, the contradiction with our results may be explained by the legal environment and investor protection in CEE countries in comparison with the origin countries of foreign investors.

Model III and Model IV estimated the effect of disclosure on foreign ownership, and foreign corporate ownership. Disclosure level has no significant impact on foreign ownership in general. These findings may be explained by the fact that foreign investors, and MNC need to base their decisions on more comprehensive analyses of financial and non-financial information regarding acquired firms. It is understood that their investment decisions are not immediate decisions, and they may involve a longer period for investigation and estimation of potential investment benefits. Thus, our $3^{\text {rd }}$ and $4^{\text {th }}$ hypotheses are not supported, a higher extent of disclosure having no significant influence on the level of foreign ownership in CEE region, at least in the short-run. Foreign investors seem to be rather oriented towards big entities, and group companies. Moreover, foreign corporate ownership is significantly 
Taran, A., Zahid, R.M.A., Mironiuc, M. (2017).

Foreign Ownership and Financial Disclosure in Central and Eastern Europe

influenced by overall level of FDI from the investing countries, which reflects the role of overall attractiveness of the country for foreign investments.

Table 4. Results of the fixed effects panel regressions.

\begin{tabular}{|c|c|c|c|c|}
\hline Variables / Statistics & Model11 & Model22 & Model333 & Model44 \\
\hline FO & $\begin{array}{c}-0.046 * * \\
(-2.23)\end{array}$ & \multicolumn{3}{|c|}{ DV } \\
\hline FOC & \multicolumn{3}{|c|}{$\begin{array}{c}-0.0510 * * \\
(-2.24)\end{array}$} & DV \\
\hline DI & DV & DV & $\begin{array}{c}0.0017 \\
(0.15)\end{array}$ & $\begin{array}{c}-0.0063 \\
(-0.79)\end{array}$ \\
\hline FRS & $\begin{array}{c}-0.0268 * * \\
(-2.12)\end{array}$ & $\begin{array}{c}-0.0267 * * \\
(-2.11)\end{array}$ & $\begin{array}{c}0.0025 \\
(0.23)\end{array}$ & $\begin{array}{c}0.0026 \\
(0.31)\end{array}$ \\
\hline GROUP & $\begin{array}{c}-0.0115 \\
(-1.08)\end{array}$ & $\begin{array}{c}-0.0117 \\
(-1.09)\end{array}$ & $\begin{array}{c}0.028 * * * \\
(3.11)\end{array}$ & $\begin{array}{c}0.015 * * \\
(2.22)\end{array}$ \\
\hline LnTA & $\begin{array}{c}0.0420 * * * \\
(7.40)\end{array}$ & $\begin{array}{c}0.0418 * * * \\
(7.37)\end{array}$ & $\begin{array}{c}0.0210 * * * \\
(4.29)\end{array}$ & $\begin{array}{c}0.0068 * \\
(1.82)\end{array}$ \\
\hline ROA & $\begin{array}{c}-0.0006 * * * \\
(-3.16)\end{array}$ & $\begin{array}{c}-0.0006 * * * \\
(-3.13)\end{array}$ & $\begin{array}{l}0.0001 \\
(0.39)\end{array}$ & $\begin{array}{c}0.0001 \\
(1.13)\end{array}$ \\
\hline MTB & $\begin{array}{c}0.0001 \\
(1.48)\end{array}$ & $\begin{array}{c}0.0001 \\
(1.46)\end{array}$ & $\begin{array}{c}0.0001 \\
(1.38)\end{array}$ & $\begin{array}{c}0.0000 \\
(0.33)\end{array}$ \\
\hline FDI_GDP & $\begin{array}{c}-0.0022 * * * \\
(-4.84)\end{array}$ & $\begin{array}{c}-0.0022 * * * \\
(-4.83)\end{array}$ & $\begin{array}{c}-0.0004 \\
(-1.13)\end{array}$ & $\begin{array}{c}-0.0008 * * * \\
(-2.52)\end{array}$ \\
\hline R-squared & 0.76 & 0.76 & 0.75 & 0.82 \\
\hline F-test & $17.26 * * *$ & $17.26 * * *$ & $16.62 * * *$ & $24.68 * * *$ \\
\hline Likelihood ratio test & & & & \\
\hline Cross-section Fixed Effects (F-Stat) & $16.07 * * *$ & $16.09 * * *$ & $15.15 * * *$ & $23.97 * * *$ \\
\hline Cross-section Fixed Effects (Chi-Square) & $9833.10 * * *$ & $9838.55 * * *$ & $9514.80 * * *$ & $12091.02 * * *$ \\
\hline $\begin{array}{l}* *, * \text { indicate statistical significance at } \\
\text {-statistics are shown in parentheses belo } \\
=\alpha_{i}+\beta_{1} F O_{i, t-1}+\Sigma_{j} \beta_{j} C_{i, j, t}+\varepsilon_{i, t} \\
=\alpha_{i}+\beta_{1} F C O_{i, t-1}+\Sigma_{j} \beta_{j} C_{i, j, t}+\varepsilon_{i, t} \\
=\alpha_{i}+\beta_{1} D I_{i, t-1}+\Sigma_{j} \beta_{j} C_{i, j, t}+\varepsilon_{i, t} \\
\begin{array}{r}i, t \\
=\end{array} \alpha_{i}+\beta_{1} D I_{i, t-1}+\Sigma_{j} \beta_{j} C_{i, j, t}+\varepsilon_{i, t}\end{array}$ & $\begin{array}{l}.01,0.05 \text { and } \\
\text { v the coefficier }\end{array}$ & $\begin{array}{l}0.10 \text { level, res } \\
\text { hts. }\end{array}$ & ctively. & \\
\hline
\end{tabular}

DI represents Disclosure Index, FO Foreign Ownership, FOC Foreign Corporate Ownership, FDI_GDP Foreign direct investment percentage of GDP, LnTA Natural Logarithm of Total Assets, FRS Financial Reporting Standards dummy variable: 0 for national accounting standards and 1 for IFRS, GROUP dummy variable: 0 for Individual financial statements and 1 for Consolidated financial statements, ROA Returns on Total Assets, MTB Market-to-Book ratio.

Overall, this study evidenced that besides all other determinants, foreign ownership influences financial disclosure of CEE listed companies. However, this empirical evidence supports only the tested hypothesis $\mathrm{H} 2$, and reveals a negative effect of foreign investors on disclosure practices of CEE companies. These findings are partially in line with previous literature, which states that influence of ownership on financial reporting may be visible under 
Taran, A., Zahid, R.M.A., Mironiuc, M. (2017).

certain circumstances (Beuselinck et al., 2017). Besides that, our results are in contradiction to Alhazaimeh et al. (2014), who found that foreign ownership determines Jordanian firms to disclose voluntary information. However, in the same time, their investigation revealed that block-holder ownership negatively reduces voluntary disclosures by a coefficient of -0.04228 (Alhazaimeh et al., 2014). This corresponds to our coefficient of foreign ownership influence on disclosure (-0.046, as shown in Table 4, Model I), and can be explained by the predominant block-holders' nature of foreign shareholders of CEE companies. Thus, the negative influence of foreign investors on future disclosure of investee entities may be seen as a characteristic of frontier and emerging markets, but further investigations are needed in order to support this inference. Jankensgard (2018) insists that mixed evidence among ownership-disclosure studies depend to research methodologies applied, but similar to our results, they found that for Swedish entities, both large and minority owners may affect disclosure negatively, at least at some points during their investment. From the perspective of our study, it was revealed that foreign ownership - disclosure association exists, and is negative in CEE region.

Greater disclosure potentially enhances market performance of reporting entities, being a mechanism of investors' protection that increases investors' confidence (Alhazaimeh et al., 2014). However, the second part of our study does not support this assumption. Our results indicate that foreign investments are not significantly influenced by the extent of financial disclosure. These findings are in line with Hansen et al. (2015) who affirmed that financial transparency may not necessarily reduce the risk of minority shareholder expropriation, if the investing countries are perceived as having a low level of investor protection. Thus, CEE countries may be perceived as attractive opportunities for portfolio and business diversification for foreign investors, but the level of transparency and financial disclosure is not a sufficient determinant of investment decisions. Our results highlight the managers' tendency to withhold information. Therefore, policy-makers may take into consideration these proofs, and further analyze the reporting practices of CEE companies, in order to design specific disclosure regulations or enforcement mechanisms, which can optimize disclosure practices of CEE reporting entities. The fact that the reverse relationship was not proven may indicate that the empirical analysis is not suspected by the endogeneity bias specific to ownership studies (Chen et al., 2014). Moreover, as indicated by descriptive statistics analysis, foreign investors in CEE are predominantly strategic corporations. Thus, the results of model II may be considered also a robustness check for the results of model I, and model IV, a robustness check for model III. To the best of our knowledge, this study may be one of the first attempts that considered the reverse relationship between foreign ownership and disclosure, and the distinction between overall ownership and strategic corporation type ownership. Moreover, it addressed this problem in the unique context of CEE region, composed by competitive emerging and frontier markets, on their path to development. Although using a limited disclosure proxy, formed by a reduced number of items, the study reveals the persistent tendency of non-disclosure of expense related items such as audit fees, audit related-fees, and generally, operating expenses covered by direct cash-flow method. 
Taran, A., Zahid, R.M.A., Mironiuc, M. (2017).

\section{Conclusions}

This study investigated the association between foreign ownership and financial disclosure tendencies of companies from Central and Eastern Europe. These aspects are particularly relevant for this region of frontier and emerging markets seeking to attract foreign investors that may boost the regional financial development. In addition, the topic is important for companies seeking for financing resources, and for financial reporting regulatory forums interested in increasing quality of regional reporting practices. Based on a mixed exploratory and explanatory approach, this research contributes by bringing this topic in the actual CEE context. Foreign ownership was regarded in a two-fold perspective, as broad group of investors with their distinctive characteristics and interest, and as corporations' type of investors. It was found that foreign investors negatively influence disclosure practices of CEE companies. The effect of foreign corporate ownership, proxying influence of multinational corporations, does not reveal a distinctive pattern in comparison to the broad category of foreign investors. The influence of multinational corporations on financial disclosure quality from operating countries tends to be aligned to secrecy accounting value dominating in the region.

On the other hand, the reverse association is not confirmed. Although disclosure can be seen as a mechanism for attracting investors, our results indicate that single items additional disclosure do not influence investment decisions of foreign investors in short-run. There are likely other mechanisms through which foreign investments can be enhanced in CEE financial markets, financial reporting indirectly contributing to their effectiveness. Moreover, the evidence provided by descriptive statistics indicate changing tendencies of disclosure in whole CEE region, reported information increasing in 2005-2011 period, and varying in the following years. This recent tendency of diminished disclosure, and its causes need to be further explored in order to assess their possible implications for financial markets and CEE developing economies.

This research shows that there is an association between foreign ownership and financial disclosure, which have practical implications for policy-makers, investors and reporting entities in the region. Although limited, due to intermediary collection of data, small number of items regarding financial disclosure, and mixture of national regulatory contexts, the empirical analysis questioned the role of financial disclosure in CEE countries, revealing that investors are not sensitive to disclosure of particular financial information in short-run, and even negatively influence the disclosure of their investees. This may be the result of monitoring and governance changes they may impose, group disclosure policies, or comparability with reporting practices from investors' country of origin. Extended research regarding the reasons behind this negative influence of investors on expenses disclosure need to be further conducted. 
Taran, A., Zahid, R.M.A., Mironiuc, M. (2017).

\section{References}

Akman, N. H., Simga Mugan, C., \& Akisik, O. (2015). Ownership Concentration Effect on Firm Performance in Turkey, Muhasebe Bilim Dünyası Dergisi, 17(1), 33-56.

Alhazaimeh, A., Palaniappan, R., \& Almsafir, M. (2014). The Impact of Corporate Governance and Ownership Structure on Voluntary Disclosure in Annual Reports among Listed Jordanian Companies. Procedia - Social and Behavioral Sciences, 129, 341 - 348. doi:10.1016/j.sbspro.2014.03.686

Barako, D.G., Hancock, P., \& Izan, H.Y. (2006). Factors Influencing Voluntary Corporate Disclosure by Kenyan Companies. Corporate Governance: An International Review, 14(2), 107-125. doi:10.1111/j.1467-8683.2006.00491.x

Beuselinck, C., Blanco, B., \& Garcia Lara, J.M. (2017). The Role of Foreign Shareholders in Disciplining Financial Reporting. Journal of Business Finance \& Accounting, 44(5-6), 558-592. doi:10.1111/jbfa.12239

Beyer, A., Cohen, D.A., Lys, T.Z., \& Walther, B.R. (2010). The financial reporting environment: Review of the recent literature, Journal of Accounting and Economics, 50, 296-343, doi:10.1016/j.jacceco.2010.10.003

Bokpin, G.A., \& Isshaq,Z. (2009). Corporate governance, disclosure and foreign share ownership on the Ghana Stock Exchange. Managerial Auditing Journal, 24(7), 688703. https://doi.org/10.1108/02686900910975387

Bradbury, M. (2011). Direct or Indirect Cash Flow Statements?. Australian Accounting Review, 21(2), 124-130. doi: 10.1111/j.1835-2561.2011.00130.x

Broberg, P., Tagesson, T., \& Collin, S.-O. (2010). What explains variation in voluntary disclosure? A study of the annual reports of corporations listed on the Stockholm Stock Exchange. Journal of Management \& Governance, 14(4), 351-377. doi:10.1007/s10997-009-9104-y

Chau, G., \& Gray, S.J. (2010). Family ownership, board independence and voluntary disclosure: Evidence from Hong Kong. Journal of International Accounting, Auditing and Taxation, 19, 93-109. https://doi.org/10.1016/j.intaccaudtax.2010.07.002

Chen, C.S. (2016). The effect of mandatory disclosure requirements and disclosure types of auditor fees on earnings management: Evidence from Taiwan. Asia Pacific Management Review, 21, 181-195. http://dx.doi.org/10.1016/j.apmrv.2015.12.002

Chen, R., Ghoul, S.E., Guedhami, O., \& Wang, H. (2017). Do state and foreign ownership affect investment efficiency? Evidence from privatizations. Journal of Corporate Finance, 2, 408-421. https://doi.org/10.1016/j.jcorpfin.2014.09.001

Chen, V.Z., Li, J., Shapiro, D.M. \& Zhang, X. (2014). Ownership structure and innovation: An emerging market perspective. Asia Pacific Journal of Management, 31(1), 1-24. https://doi.org/10.1007/s10490-013-9357-5

Choi, S.B., Park, B.I., \& Hong, P. (2012). Does Ownership Structure Matter for Firm Technological Innovation Performance? The Case of Korean Firms. Corporate Governance: An International Review, 20(3), 267-288. doi:10.1111/j.14678683.2012.00911.x

DeFond, M., Hu, X., Hung, M., \& Li, S. (2011). The impact of mandatory IFRS adoption on foreign mutual fund ownership: The role of comparability. Journal of Accounting and Economics, 51, 240-258. doi:10.1016/j.jacceco.2011.02.001

Douma, S., George, R., \& Kabir, R. (2006). Foreign and Domestic Ownership, Business Groups, and Firm Performance: Evidence from a Large Emerging Market. Strategic Management Journal, 27, 637-657. doi:10.1002/smj.535 
Taran, A., Zahid, R.M.A., Mironiuc, M. (2017).

Fang, V.W., Maffett, M., \& Zhang, B. (2015). Foreign Institutional Ownership and the Global Convergence of Financial Reporting Practices. Journal of Accounting Research, 53(3), 593-631. doi:10.1111/1475-679X.12076

Guay, W., Samuels, D., \& Taylor, D. (2016). Guiding through the Fog: Financial statement complexity and voluntary disclosure, Journal of Accounting and Economics, 62, 234269. http://dx.doi.org/10.1016/j.jacceco.2016.09.001

Hansen, B., Miletkov, M.K., \& Wintoki, M.B. (2015). Investor Protection and the Role of FirmLevel Financial Transparency in Attracting Foreign Investment. The Financial Review, 50, 393-434. doi:10.1111/fire.12072

Hoque, M., \& Rakow, K.C. (2016). Do voluntary cash flow disclosures and forecasts matter to value of the firms?. Managerial Finance, 42(1), 3-12. doi:10.1108/MF-09-2015-0253

Hsu, M.-F., \& Wang, K. (2014). The Level and Stability of Institutional Ownership and Firm Performance: Evidence from Taiwan. Emerging Markets Finance and Trade, 50(sup.2), 159-173. doi: 10.2753/REE1540-496X5002S211

Imam, M.O., \& Malik, M. (2007). Firm Performance and Corporate Governance Through Ownership Structure: Evidence from Bangladesh Stock Market. International Review of Business Research Papers, 3(4), 88-110. http://ssrn.com/abstract=2256480

Jankensgård, H. (2018). Between a rock and a hard place: New evidence on the relationship between ownership and voluntary disclosure. International Review of Financial Analysis. 56. 281-291. https://doi.org/10.1016/j.irfa.2017.09.009

Khanna, T., Palepu, K.G., \& Srinivasan, S. (2004). Disclosure Practices of Foreign Companies Interacting with US Markets. Journal of Accounting Research, 42(2), 475-508. doi:10.1111/j.1475-679X.2004.00146.x

Leung, E., \& Verriest, A. (2015). The Impact of IFRS 8 on Geographical Segment Information. Journal of Business Finance \& Accounting, 42(3-4), 273-309. doi:10.1111/jbfa.12103

Mangena, M., \& Tauringana, V. (2007). Disclosure, Corporate Governance and Foreign Share Ownership on the Zimbabwe Stock Exchange. Journal of International Financial Management and Accounting, 18(2), 53-85. doi:10.1111/j.1467-646X.2007.01008.x

Nakano, M., \& Nguyen, P. (2013). Foreign ownership and firm performance: evidence from Japan's electronics industry. Applied Financial Economics, 23(1), 41-50. http://dx.doi.org/10.1080/09603107.2012.705425

Nashier, T., \& Gupta, A. (2016). The Effect of Institutional Ownership on Firm Performance. IUP Journal of Corporate Governance, 15(3), 36-56.

Scaltrito, D. (2016). Voluntary disclosure in Italy. Firm-specific determinants an empirical analysis of Italian listed companies. EuroMed Journal of Business, 11(2), 272-303. doi:10.1108/EMJB-07-2015-0032

Thomsen, S., \& Pedersen, T. (2000). Ownership structure and economic performance in the largest European companies. Strategic Management Journal, 689-705. DOI: 10.1002/(SICI)1097-0266(200006)21:6<689::AID-SMJ115>3.0.CO;2-Y

Wang, K., Sewon, O., \& Claiborne, M. C. (2008). Determinants and consequences of voluntary disclosure in an emerging market: Evidence from China. Journal of International $\begin{array}{llll}\text { Accounting, Auditing and 14-30. } & \text { 17), }\end{array}$ doi:10.1016/j.intaccaudtax.2008.01.001

Xia, F., \& Walker, G. (2014). How much does owner type matter for firm performance? Manufacturing firms in China 1998-2007. Strategic Management Journal, 36(4), 576 585. doi:10.1002/smj.2233

Zimmermann, J., \& Werner, J.R. (2013). Regulating Capitalism? The Evolution of Transnational Accounting Governance, Hampshire: Palgrave Macmillan. 